\title{
VTR 用ガイドローラの鳴きと振動特性*
}

\author{
矢 鍋 重 $*^{* 1}$, 小 林 裕 介 $^{* 2}$, 麻生川 克憲*2
}

\section{Squeal and Vibration Characteristics of VTR Guide Roller}

\author{
Shingo YANABE*3, Yusuke KOBAYASHI and Katsunori ASOGAWA \\ ${ }^{* 3}$ Department of Mechanical Engineering, Nagaoka University of Technology, \\ 1603-1 Kamitomioka, Nagaoka-shi, Niigata, 940-2188 Japan
}

\begin{abstract}
Squeal and vibration characteristics of a VTR (video tape recorder) guide roller are investigted experimentally and a mechanism of squeal generation is considered. The results show that the squeal frequency (about $2 \sim 5 \mathrm{kHz}$ ) is the same as the guide roller vibration (whirl) frequency and it is 35 $\sim 60$ times larger than the guide roller rotational speed $(50 \sim 110 \mathrm{rps})$ in most cases. The guide roller rotates and whirls in the tape running direction (a forward whirl) with a nearly circular vibration orbit. The whirl (squeal) frequency can be estimated from the assumption that the guide roller rotates and whirls around the fixed shaft without slip. These indicate that the squeal generates by means of a guide roller forward whirl due to a dry friction acting between the guide roller and shaft.
\end{abstract}

Key Words : Noise, Squeal, Vibration of Rotating Body, Friction Vibration, VTR Device, Guide Roller

\section{1. 粕 諭}

近年, VTR機器が広く普及している. しかし, テープ巻き戻し過程の高速化に伴い, テープの安定走 行を目的として設置したガイドローラに鳴きが発生し やすくなってきている. 従来, ガイドローラの製造現 場では，ローラの摺動性，ローラと軸のすきま，軸の 支持方法などを工夫して鳴き発生に対処してきたが, 鳴きの特徴，鳴き発生時のガイドローラや軸の振動挙 動, 鳴きの発生メカニズムなどについてはほとんど研 究されていない：ここで, 鳴きとは, 摩徖が原因で高 周波の振動が系の一部または全体に生じ高い音が発生 する現象をいう.

これまで自動車のブレーキ, クラッチ, タイヤ, 鉄道用車輸などの鳴きに関して膨大な研究が行なわれ てきたが，これらの鳴きは関䡛因子が多く，鳴きの特 徴や発生機構が複雑で十分には解明されていない，鳴 きの主な発生メカニズムには，次の二つがあるように 思われる. (1)摩擦力ーすべり速度特性の負の傾きが主 原因で, 回転弾性体と接触体から成る連成振動系の固 有振動数のひとつが負減衰になり不安定振動(鳴き)が 発生する場合で，鳴きの周波数は回転速度によらずほ ぼ一定になる゙!（2)すべり速度に依存せず常に一方向 に作用する大きさ一定の摩擦力が回転弾性体と接触体

* 原稿受付 2003 年 10 月 3 日.

*1 正員, 長岡技術科学大学工学部( $340-2188$ 長岡市上富岡 町 1603-1).

*2 長岡技術科学大学大学院工学研究科.

E-mail : yanabe@ mech.nagaokaut.ac.jp
から成る連成振動系に作用し, ある特定の条件下で, 摩擦力のモーメントが系の回転運動に対して一種の負 のばねとして働いたり，摩擦力のモーメントが振動の 1 サイクル中に系に正の仕事をしたりする結果, 不安 定振動が発生する場合であるたの. しかしながら，後 述するようにガイドローラの場合は鳴きの周波数がロ 一ラ回転速度の 35〜60 倍と高く, 先に述べた鳴きの 特徴と大きく違うため, 鳴きの発生メカニズムも異な ると考えられる.

本研究では, テープ走行系を 2 個のプーリ間を走 行するベルトで模したガイドローラ回転試験装置を用 いて, モータ回転速度, ローラのベルトへの押しつけ カ, ローラと軸のすきまなどを変化させて, ガイドロ 一ラの騷音・振動を測定し，鳴きや振動の特徵および 鳴きの発生メカニズムを実験的に明らかにすることを 目的としている.

\section{2. 实険装置および实険方法}

21 实験装置図 1 に実験装置概略, 図 2 に供 試ガイドローラの構造を示す. 実験装置は, ベルト走 行系, 供試ガイドローラ、ガイドローラ押しつけ機構 から成っている. 測定系は, 駆動プーリ回転速度測定 用およびガイドローラ振動測定用の渦電流式非接触変 位計, 騒音測定用マイクロフォン, FFT 分析器から構 成されている. ガイドローラは回転するローラとこれ を支持する上下フランジ付きの鋼製片持ち軸から構成 されている. ガイドローラは内部がポリアセタール樹 脂, 外周が厚さ $0.5 \mathrm{~mm}$ のステンレス円筒からなり, 質 
量約 $1.4 \mathrm{~g}$ である. ベルトは長さ $381 \mathrm{~mm}$ ，幅 $4 \mathrm{~mm}$ ，厚 さ $0.4 \mathrm{~mm}$ である.

22 実験方法 鳴きを発生しやすい 6 個のガイ ドローラ(No2,3,4,5,6,7, №.1 は鳴きを発生しないローラ) を選んで実験を行った. 図 1で，片持ち支持した供試 ガイドローラを走行中のベルトに押しつけ，駆動プー リ回転速度を $100 \sim 5800 \mathrm{~mm}$ の範用で上昇・下降させ, ガイドローラの騷音・振動を測定した. ガイドローラ 回転速度はベルトとのすべりがない場合, 駆動プーリ 回転速度の 9.91 倍 (=68.9 / 6.95 : ローラ直径比)である. 騒音計はガイドローラから水平方向に約 $200 \mathrm{~mm}$, 垂 直方向に約 $150 \mathrm{~mm}$ 離した位置に設置した. 図 2 のガ イドローラと軸の間の半径すきまは, ローラ部を指で 保持して旋回させ，その時の変位軌跡を直角 2 方向に 配置した 2 個の非接触変位計で測定して求めた. №2 〜7ガイドローラの半径すきまは表 1 に示す通りであ る. 特にことわらない限りベルト初期張力 T $\mathrm{T} 190 \mathrm{~N}$, 押しつけ力 $\mathrm{P}=0.098 \mathrm{~N}$ で実験を行った. また, 以下の 説明では次の記号を用いる.

$N \mathrm{rpm}$ : 駆動プーリ回転速度

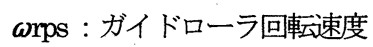

$\boldsymbol{Q} \mathrm{Hz}:$ ガイドローラの鳴きの周波数 =ガイドローラの振動(ふれまわり)の振動数

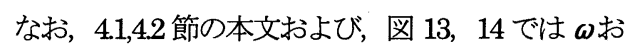
よび $\boldsymbol{Q}$ の単位を $\mathrm{rad} / \mathrm{s}$ としている.

\section{3. 実験 結果}

3.1 ガイドローラの鳴きの特幑 図 1 の装置で、 駆動プーリ回転速度をゆるやかに上昇させた場合のガ イドローラの騒音測定例を図 3 に示す. 図より，ガイ ドローラ No3, 4, 5 は回転速度 3800, 4300, 3900 pm でそれ ぞれ騒音レベルが急増し，鳴きが発生していることが わかる. №.4 ガイドローラについて 300〜 5800 pm の $100 \mathrm{rm}$ 毎の回転速度における騒音およびローラの振動 の周波数分析結果を図4(a)，(b)にそれぞれ示す. 図より 騒音振動ともに $4300 \mathrm{pm}$ 以上で約 $4.8 \mathrm{kHz}$ のピークが存 在することから, 鳴きはガイドローラの振動が原因で あると考えられる. 図4(a)には9〜10kHzに小さな騷音 成分があること, 図 4(b) の低振動数領域にはガイドロ 一ラ回転速度 $\omega$ の 1 次の成分が見られ, 4300 rmm で鳴 きが発生するとこの值がかなり小さくなっていること がわかる. 鳴きの発生回転速度や鳴きの周波数は供試 ガイドローラによって異なり, また同じガイドローラ でも測定した日により $5 \%$ 程度の違いがあった.

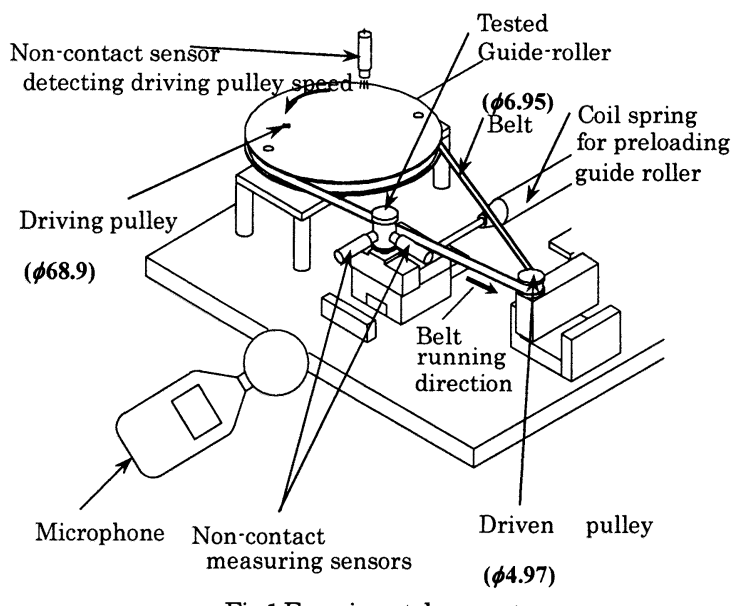

Fig.1 Experimental apparatus

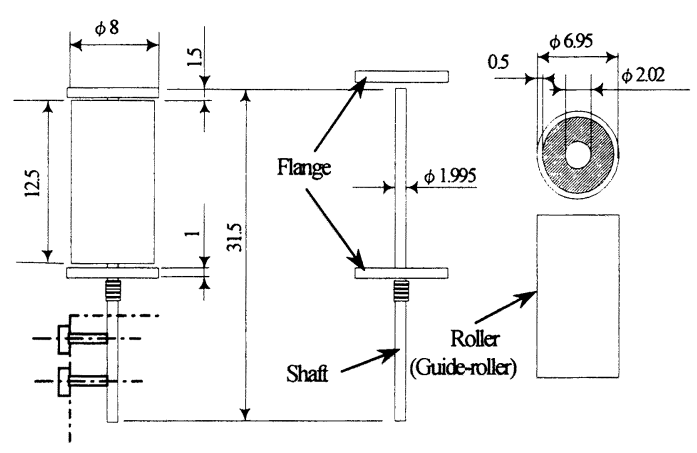

Fig.2 Shape of guide-roller

Table.1Radial gaps between guide roller and shaft

\begin{tabular}{|c|c|c|c|c|c|c|}
\hline & No2 & No3 & No.4 & No.5 & No.6 & No.7 \\
\hline $\begin{array}{c}\text { Radial gap } \\
{[\mu \mathrm{m}]}\end{array}$ & 27 & 30 & 29 & 38 & 28 & 28 \\
\hline
\end{tabular}

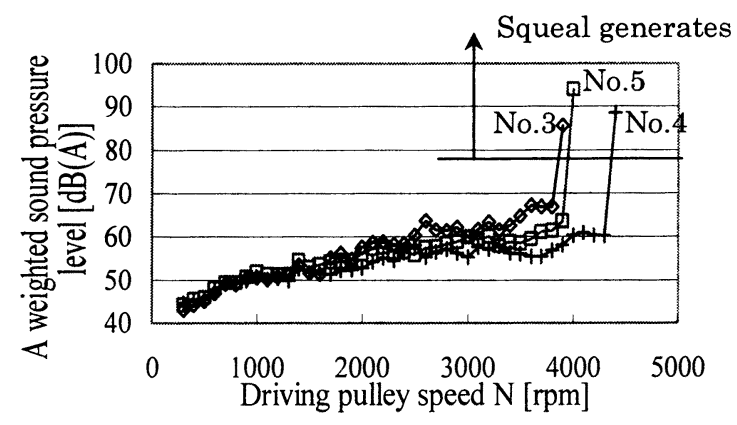

Fig.3 Measured sound pressure level of guide-rollers (In increasing driving pulley speed, No.3,4,5 guiderollers) 


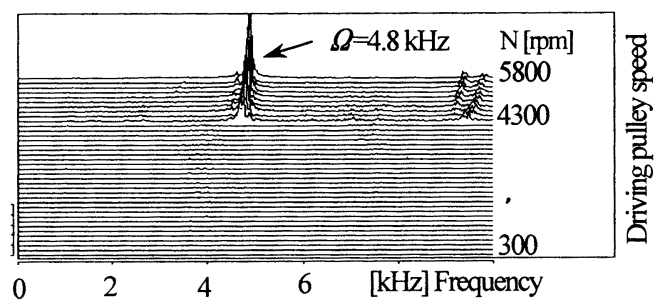

(a) Noise FFT results



Fig.4 Results of FFT analysis (No.4 guide-roller)

32 鳴きの周波数 $\Omega$ とガイドローラ回転速度 $\omega の$ 関係 ( $\Omega$ - $\omega$ 曲線)

$321 \Omega$ - $\omega$ 曲線 No.7ガイドローラについて, 駆動プ 一リ回転速度 $N$ の増減速時におけるガイドローラ回 転速度 $\boldsymbol{\omega}$ およひ鳴きの周波数 $\boldsymbol{\Omega}$ の変化を実測し，そ の結果を図 5 に $\boldsymbol{\omega}-\boldsymbol{N}, \boldsymbol{\Omega}-\boldsymbol{N}$ 曲線として示す. ガイドロ 一ラ回転速度 $\omega$ (図中の黒太線)は, はじめ, 駆動プー リ回転速度のほぼ 9.91 倍で増加し, ベルトとガイドロ 一ラ間のすべりはほとんど無い. $3000 \mathrm{pm}$ 付近でガイ ドローラを打撃し強制的に鳴きを発生させると $\omega$ が 急激に低下し(図中の(1)), ベルト・ガイドローラ間に大 きなすべりが生じる. この状態で $N$ を増加させると $\omega, \Omega$ は漸减する. $N=5500 \mathrm{pm}$ (図中の(2) 加 $N$ 減少 させると $\omega, \boldsymbol{\Omega}$ は漸増し，鳴きはかなり低速まで持続 する. 低速域ではベルト・ガイドローラ間のすべりは 小さくなる，鳴きは供試ガイドローラによって異なる が，200６00 pm で消滅する(鳴き発生限界). $N$ 増加時 にガイドローラを打撃すると, 鳴き発生限界より高速 側では，常に鳴きが発生する. 図 5 の鳴き発生状態で $N$ の増速過程(1)-(2)拉よび咸速過程(2)-(3)ー(4)にお ける，鳴きの周波数一ガイドローラ回転速度特性 $(\Omega-\omega$ 曲線) を描くと図 6(a)，(b)が得られる. 増减速時の二つ の図の測定結果はほとんど重なり, 鳴きの周波数 $\boldsymbol{\Omega}$ $\mathrm{Hz}$ とガイドローラの回転速度 $\boldsymbol{\omega} \mathrm{rps}$ はほぼ比例関係 $\boldsymbol{\Omega}$ ○60心にあることがわかる(A型の鳴き). 比例係数が 60 と極めて大きい.

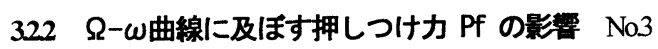
ガイドローラについて, ベルトへの押しつけ力 Pfを $0.069 \mathrm{~N} \sim 0.147 \mathrm{~N}$ の範囲で 5 通りに変えて実験を行い,得

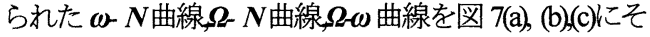
れぞれ示す.これらの結果は, 鳴き発生後駆動プーリ 回転速度を 4500 5000 $\mathrm{pmm}$ に上げ，その後，減速しな
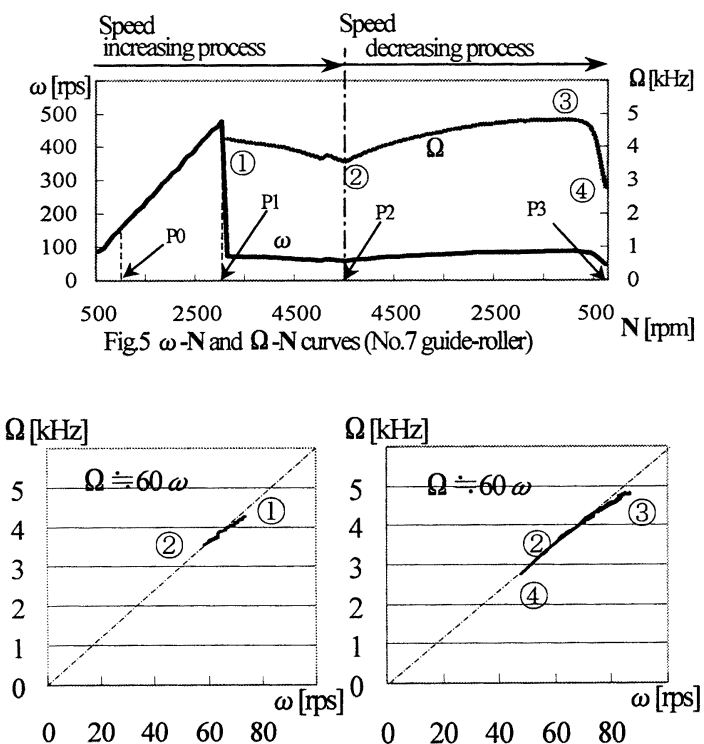

$\begin{array}{ll}\text { (a) Speed increasing process } & \text { (b) Speed decreasing process }\end{array}$

Fig.6 $\Omega-\omega$ curve(No.7 guide-roller)
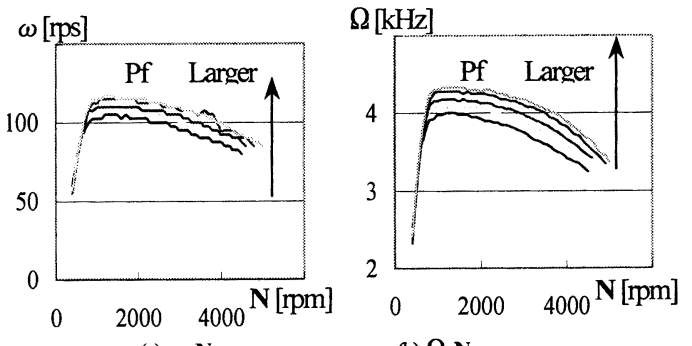

(a) $\omega$-Narves

(b) $\Omega$-Narves

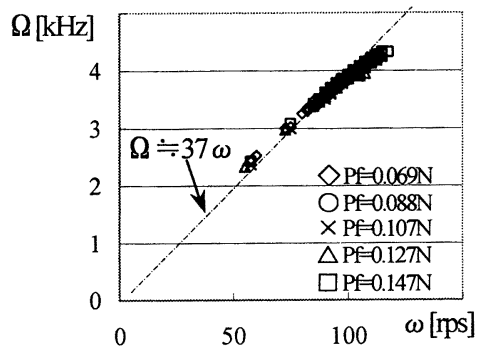

(c) $\Omega$ - $\omega$ arves

Fig.7 Effect of pushed force Pf(No.3 guide-roller) 
がら測定したものである. 図7(a) (b)より，押しつけ力 Pf が大きくなるとガイドローラ回転速度 $\omega$ およひ鳴


Pfの值によらずほぼ一本の曲線 $\Omega \div 37 \omega$ の直線)になり, ガイドローラ押しつけ力 Pf は $\boldsymbol{~} \boldsymbol{~} \boldsymbol{\omega}$ 曲線にあまり影響 しないことがわかる. また，プーリ軸間距離を調整し ベルト初期張力 Ti を 1.47〜 245N の範用で変化させて 実験を行ったが，Ti も $\boldsymbol{\Omega} \boldsymbol{\omega}$ 曲線にあまり影響しない ことがわかった. №.4 ガイドローラについて Pfを変 えて同じ央験を行ったところ，図8のような $\Omega \omega$ 曲線 が得られた.この場合, $\Omega \boldsymbol{s} \omega$ 曲線は $\Omega \div 40 \omega$ と(A型の 鳴き) $2 \div 4.5 \mathrm{kH}$ (一定, B型の鳴き)の 2 本の直線力ら成 ることがわかるが，その理由は不明である. なお,こ のような特性を示したのは №.4 ガイドローラだけで あった。

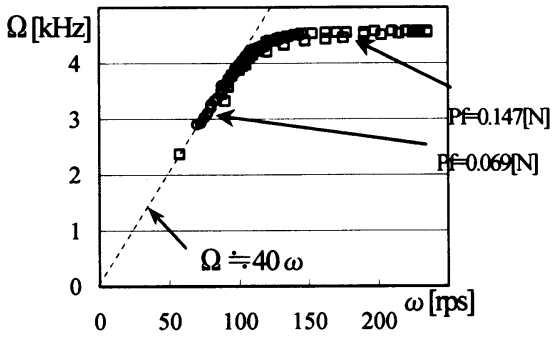

Fig. $8 \Omega \cdot \omega$ curve of No.4 guide roller

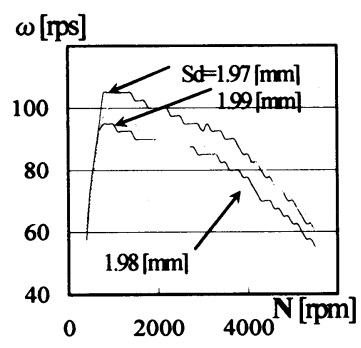

(a) $\omega-\mathrm{N}$ curves

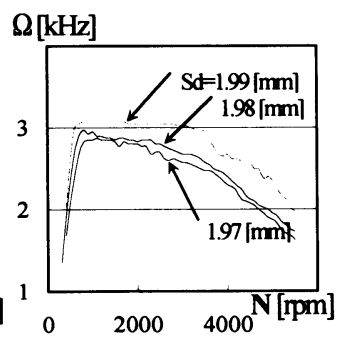

(b) $\Omega-N$ curves

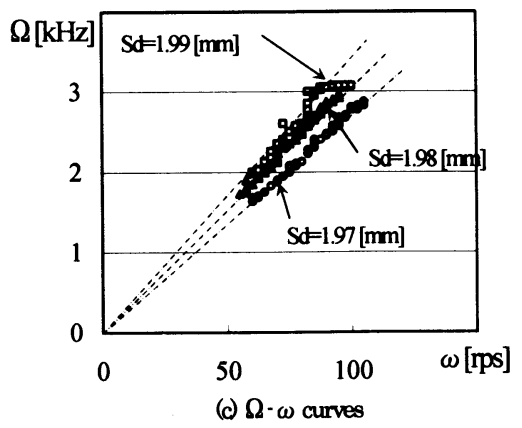

Fig.9 Effects of shaft diameter $\operatorname{Sd}$ on $\Omega-\omega$ curves
$323 \Omega$ - $\omega$ 曲線に及ほす䛆直径 Sd の影霓 直径の異 なる3本の軸(Sd=199, 1.98, $1.97 \mathrm{~mm})$ を製作し， ローラ 1 個を共通にしてガイドローラを組み立て実験を行なっ た. このときの鳴き発生時の $\omega \mathbf{N}$ 曲線および $\boldsymbol{\Omega} \boldsymbol{N}$ 曲 線を図 $9(\mathrm{a})$,(b)k，両図加得た $\Omega \omega$ 曲線を図 $9(\mathrm{c})$ にそ れぞれ示す. 図 9(a)，(b)より, 軸直径が小さいと(半径 すきま $\varepsilon$ が大きいと), 鳴きの周波数が低くなる傾向 にあるが，ガイドローラ回転速度については一定の傾

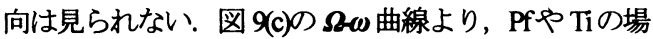
合と異なり，Sd が大きくなると, 同じ回転速度 $\omega$ に 対して鳴きの周波数が高くなることがわかる.

33 ガイドローラおよひ軸の振動軌跡図 5 に 示した代表的な回転速度 $\mathrm{P} 0 \sim \mathrm{P} 3$ において，ガイドロ 一ラ中央部および軸の上フランジ部の振動軌跡を図 10 に示すような変位センサ一配置で測定した. 結果 を図 11(a) 〜d)に示す. 各図左上の矢印 $\rightarrow$ ばルトの 走行方向を, 図中の曲がった矢印は軌跡の運動方向を, 数字は軌跡の大きさ $(\mu \mathrm{m})$ を示している. 図 11(a)は鳴き が発生していない時, 図 11(b) (c) は鳴き発生直後およ び最高回転速度, 図 11(d)は鳴き消㓕直前の回転速度 の結果である. 図 11(a) より，鳴きが発生していない 通常回転時では軸は振動せず，ガイドローラは回転し ながらベルト走行方向にわずかに振動していることが わかる. 図 11(b) (d)の鳴き発生中は，ガイドローラは ベルト走行方向にほぼ軌跡を描きながら大きく振れ まわっている(前向き振れまわり). 軸もほぼ円軌跡を 描きながらローラと同じ方向に同じ振動数で振動して いる. 図 11(b)におけるローラ(中央部)と軸(上フランジ 部の振動の時間波形は図 12 に示す通りで，両者はほ ぼ逆位相であることがわかる. 図 11(b)〜(d)でローラや 軸の振動軌跡の大きさが変化する理由や，図 11(c)で軌 跡が乱れる理由は現在のところ不明である.

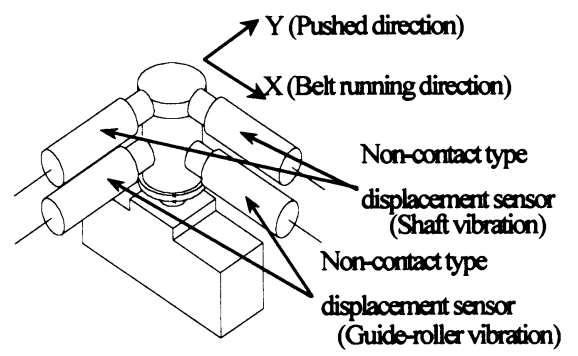

Fig.10 Vibration measuring system 

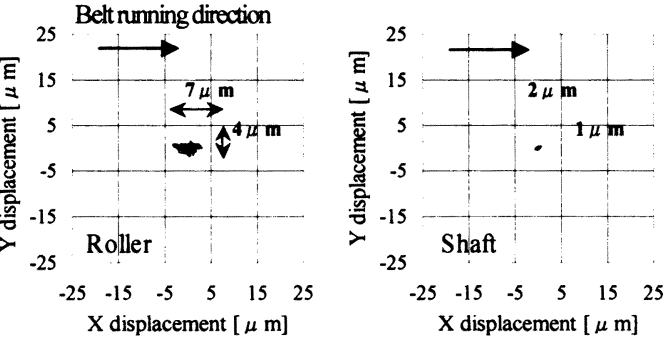

(a) At $1000 \mathrm{rpm}$ (P0)


(b) At $3000 \mathrm{rpm}$ (P1)
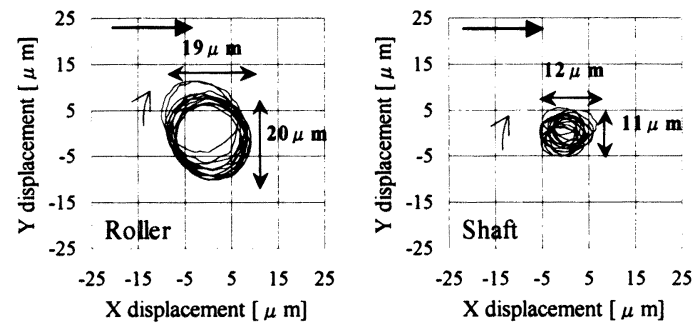

(c) At $5500 \mathrm{rpm}(\mathrm{P} 2)$
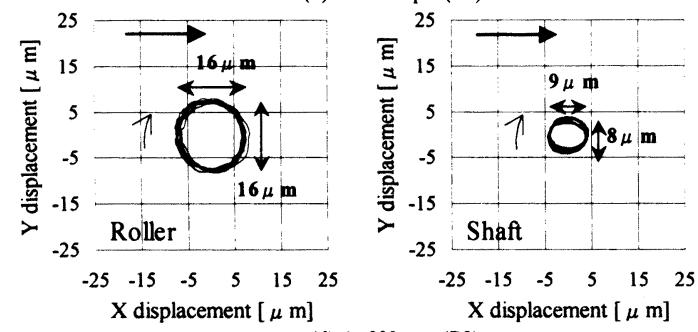

(d) At $300 \mathrm{rpm}$ (P3)

Fig.11 Vibration orbits of guide-roller ard shaft (No.7 guide roller)

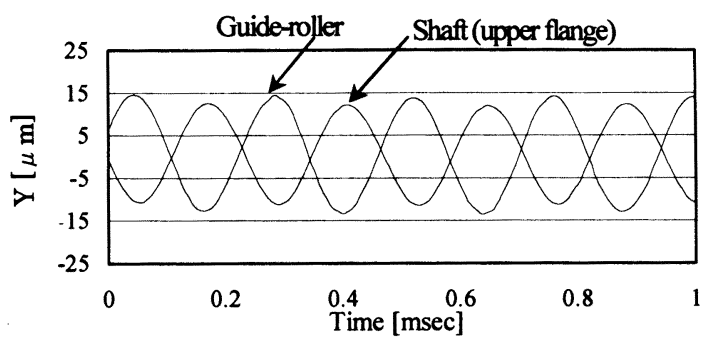

Fig.12 Vibration waveforms of guide roller and shaft (No.7 guide-roller, at $3000 \mathrm{rpm}$ )
実験終了後，鳴きを発生したガイドローラのロー ラと軸のすきまに潤滑油を一滴入れて回転試験を行な ったが， $5500 \mathrm{~mm}$ までの範囲ではガイドローラを打撃 しても鳴きやローラの大きなふれまわりは発生しなか った. 以上より,ガイドローラと軸の間の乾性摩擦が ガイドローラの鳴き発生に大きな影響を及ぼしている と考えられる. また, ガイドローラの軸だけの曲げ 固有振動数は約 $15 \mathrm{kHz}$ であったが，ローラを含めた 系の固有振動数を得るのは困難であった.

\section{4. ガイドローラの膞きに関する考察}

41 考察の基磷 3.章で示した実験結果から，ガ イドローラの鳴きはローラ・軸間の乾性摩擦力によっ てガイドローラが高い振動数で前向きにふれまわる結 果と考えられる. 従来, 回転体がケーシングなどの静 止部に接触し, その乾性摩擦力によって激しい後向き ふれまわりが発生することはよく知られているののも のの, 高い振動数の前向きふれまわりが発生したとい う報告はない，図 13 は，後向きふれまわりの発生メ カニズムおよびその振動数を求めるための説明図であ る. 半径 Rの大きな円は固定されたケーシングの内周 を表し, 半径 $r$ の円は角速度 $\omega$ で回転する回転軸を表 す. 摩擦力によって回転軸がケーシングの内周をすべ らずに転がる場合，両者の接触点は現在の $P, P^{\prime}$ から

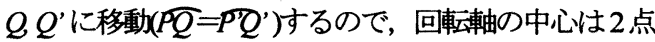
鎖線の円上を $\boldsymbol{\omega}$ と逆方向に角速度 $\boldsymbol{\Omega}$ で旋回する（後 向きにふれまわる），回転軸上の現在の接触点 $P$ の 速度 $\Omega \Omega-r \omega$ をゼロと置くことにより, 後向きふれ まわりの角速度 $\boldsymbol{\Omega}$ は式(1)のように得られる゙す。

$$
\Omega=(r / \varepsilon) \omega
$$

式(1)中の半径すきま $\mathrm{g}=R \rightarrow \boldsymbol{r})$ は軸半径 $r$ に比べて十分 小さく $r / \varepsilon=10 \sim 100$ 程度となり, かなり高速の後向き ふれまわりが発生する。

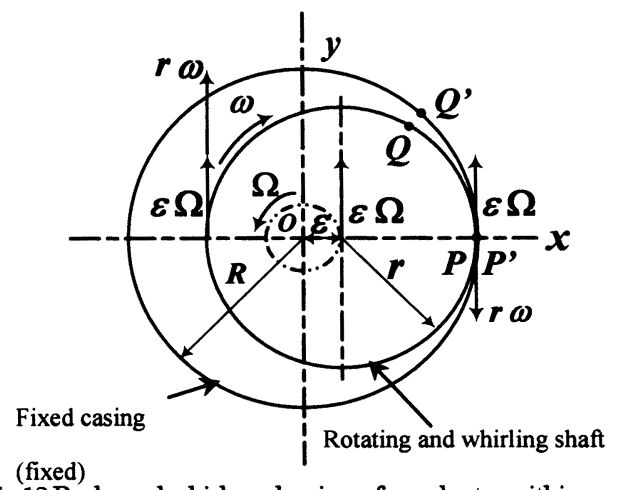

Fig.13 Backward whirl mechanism of usual rotor within casing (inner rotor system) 


\section{2 ガイドローラの前向きふれまわりの発生メカ}

ニズム 4.1 の考察をもとに, 図 14 に示すモデルで ガイドローラの前向きふれまわりの発生メカニズムお よびその振動数を考える. 図中, 半径 $r$ の小さな円は 固定された軸を表し，半径 $R$ の大きな円は角速度 $\omega$ で回転するガイドローラの内周を表す. ガイドローラ の内周が静止している軸外周をすべらずに転がると仮 定すると，両者の接触点は現在の $P, P^{\prime}$ から $Q Q^{\prime}$ に移

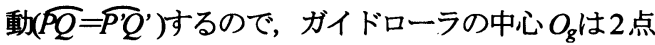
鎖線の円上を $\boldsymbol{\omega}$ と同じ向きに角速度 $\boldsymbol{\Omega}$ で旋回する(前 向きにふれまわる).このとき, ローラ内周上で軸と 接触する点 $P$ の速度 $\Omega \Omega-R^{\prime} \omega$ をぜ口と置くことに より, 前向きふれまわりの振動数 $\boldsymbol{\Omega}$ は次のように得 られる.

$$
\Omega=(R / \varepsilon) \omega
$$

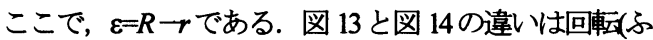
れまわり)する要素が静止している要素の内側にある か外側にあるかで, ふれまわりの向きが後向きまたは 前向きになることである.

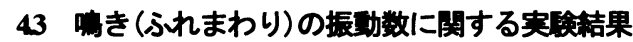
と式(2)の比较 $\quad \mathrm{N} 05,7$ ガイドローラの $\boldsymbol{\Omega} \boldsymbol{\omega} \boldsymbol{\omega}$ 曲線 (実験結果) と式(2)の結果を比較したのが図 15(a),(b) である. 式(2)の計算に必要なガイドローラと軸の半径 すきま $\varepsilon$ の值は表 1 に示してある (R=1.01mm). 図 15(a) (b)より，実測した $\boldsymbol{\Omega}$ の値は式(2)の結果より大きくな っている.これは，実験では鳴き発生時にガイドロー ラの軸が大きく振動しているのに(図 11 参照)，式(2)は 軸の振動を考虑していないためと考えられる.

44 再实険 ここでは, 鳴き発生時でもガイド ローラの軸の振動が十分小さくなるように, 軸を両持 ちで支持する治具を製作し(図 16 参照)再実験を行った。 鳴き発生直後の回転速度におけるガイドローラと軸上 部の振動軌跡の測定結果を図 17 に示す.

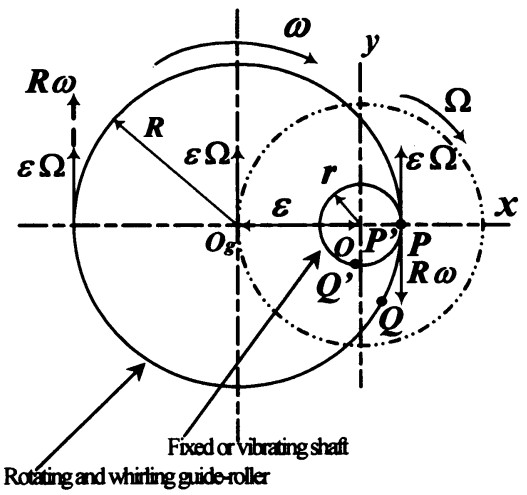

Fig.14 Forward whirl mechanism of guide roller • shaft system (outer rotor system)

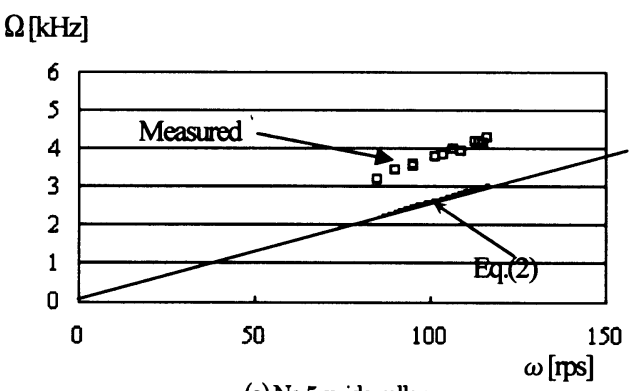

$\Omega\lceil\mathrm{kHz}\rceil$

(a) No.5 guideroller

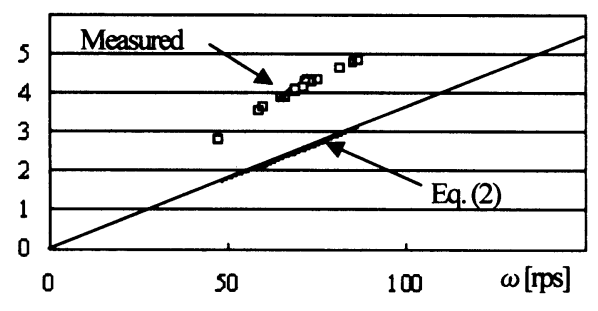

(b) No.7 guide roller

Fig.15 Comparison between estimated squeal frequencies Eq.(2) and measured values

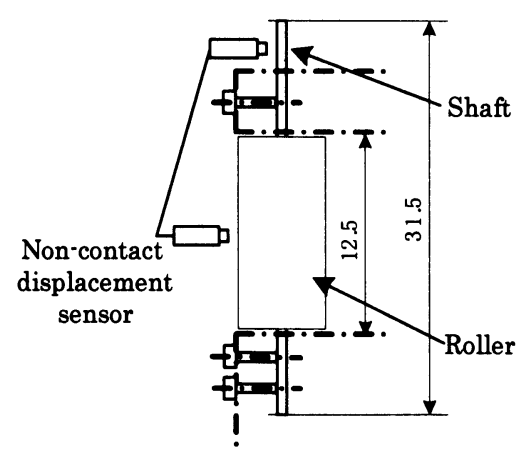

Fig.16 Guide-roller supported at both ends (new guide-roller)

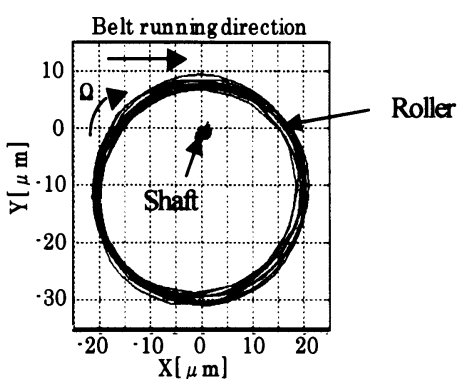

Fig.17 Vibration orbits of guide-roller and shaft (new guide-roller at $1500 \mathrm{rpm}$ ) 
$\Omega[\mathrm{kHz}]$

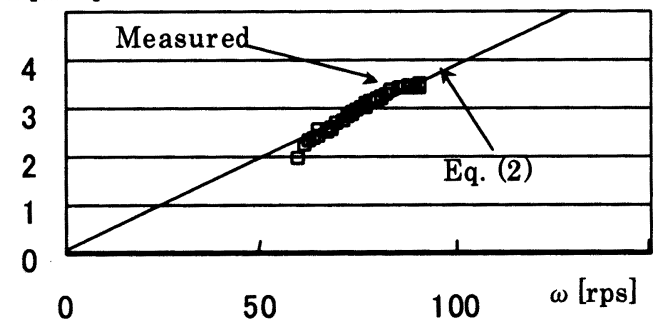

Fig.18 Comparison between estimated squeal frequencies and measured values (new guide-roller)

図 17 より,ガイドローラの軸はほとんど振動してい ないことがわかる. 図 18 に実測した $\Omega \omega$ 曲線および 式(2)の計算結果を示す. 図より, 両者の結果はかなり よく一致しており, 図 14 に示した前向きふれまわり モデルの妥当性を確認できたと考える.

\section{5. 結}

ガイドローラ回転試験装置を用いて，いくつかの パラメータの值を変化させて実験を行い, ガイドロー ラの鳴きや振動の特徵およひ鳴きの発生メカニズムに ついて下の知見を得た。

（1）駆動プーリ回転速度をゆっくりと増加させた場 合，供試ガイドローラによって異なるが， $3500 \mathrm{mpm}$ (ベルト速度 $126 \mathrm{~m} / \mathrm{s}$ )以上の高速域でガ イドローラに周波数 2〜5 kHz の鳴きが発生した. 鳴きの周波数はガイドローラの振動(ふれまわり) の振動数に等しい，鳴きは衝撃を加えると低速 域でも発生する. また, 一度発生した鳴きはか なり低速になるまで消㓕しない，鳴き発生限界 度は駆動プーリ回転速度で 200 600 rpm(ベルト 速度 $0.7 \sim 2 \mathrm{~m} / \mathrm{s}$ )であった.

(2) ガイドローラのベルトへの押しつけカが大きい ほど, 鳴きの周波数およひ鳴き発生時のガイド ローラ回車速度は高くなる.

（3）鳴きの周波数は，ほとんどの場合，ガイドロー ラ回転速度に比例して変化する(A型の鳴き). 比 例定数は 35〜60でガイドローラによって異なり, ガイドローラと軸のすきまが小さい程, 比例定 数は大きい，鳴きの周波数が一定で, ガイドロ 一ラ回転速度に無関係な場合(B型の鳴き)も見受 けられた。

（4）鳴き発生時, ガイドローラはベルト走行方向に, 鳴きの周波数と同じ振動数でほぼ円軌跡を描い て前向きにふれまわる. 軸が片持ち支持の場合,
軸は大きく振動するが，軸が両持ち支持の場合， 軸はほとんど振動しなくなる.

（5）ガイドローラの鳴きは，ローラの前向きふれま わりによって発生する. この前向きふれまわり は, A型の鳴きでは, ローラと軸の間の乾性摩 擦により, ガイドローラ内周が軸外周上をすべ らずに転がる結果生ずる．軸がほとんど振動し ない場合の鳴きの周波数(=前向きふれまわりの 振動数 $\boldsymbol{Q} \mathrm{Hz}$ は, ガイドローラの回転速度 $\omega \mathrm{rps}$, 内半径 $R$ ， ローラと軸の半径すきま $\varepsilon$ を用いて ほぼ $\Omega=(R / \varepsilon) \omega$ で推定できる. なお, $\mathrm{B}$ 型 の鳴きの発生メカニズム解明は今後の課題であ る.

\section{謝辞}

本研究の問題提起，実験装置の製作および有益な ご助言を頂きましたケミコンアドバンスビジネス株式 会社長岡事業所任藤正之所長, 剣特徳夫氏, 松本博氏 に厚く御礼申し上げます。.また, 結果の考察に関して は, 埼玉大学工学部佐藤勇一教授に有為なご助言を頂 きました. 厚く御礼申し上げます.

\section{妾文献}

[1] 横井雅之, 中井幹雄, 機論 C, 45-391，(1979-3), 346-355.

[2] Earles,S.W. and Soar, G.B, Inst. Mech Engr., C107/71,6169.

[3] 太田和秀, 香川光二, 江藤俊夫, 西川進, 機論 C, 50-457,(1984-9), 1585-1593.

[4] 栗田裕, 岩本弘, 機論 C, 51-467, (1985-7), 172511730.

[5] 谷口修蝙，振動工学ハンドブック，(1976), 960962, 養賢堂.

[6] S.チモシェンコ, 工業振動学 第 3 版(谷下市 松・渡辺茂訳)，(1956)，107-108，東京図書.

[7] Black,HF, JMechanical Engineering Science,101,(1968),1-12

[8] Bartha,AR, Disertation ETH No.13817,Dry Friction Backwand whinl of Rotors (2000).

[9] 矢鍋重夫ほか 2 名、機論，65634, C(19996)，22112217. 